Int. J. Electrochem. Sci., 13 (2018) 12294 - 12310

International Journal of

ELECTROCHEMICAL

SCIENCE

www.electrochemsci.org

\title{
Monotriazoles Derived from Uracil and Thymine as Corrosion Inhibitor for API 5L X52 Steel in $1 \mathrm{M} \mathrm{H}_{2} \mathrm{SO}_{4}$
}

\author{
A. Espinoza-Vázquez ${ }^{1 *}, F$. J. Rodríguez-Gómez ${ }^{1}$, Guillermo E. Negrón-Silva ${ }^{2}$, D. Angeles-Beltrán ${ }^{2}, R$. \\ González-Olvera ${ }^{3}$.
}

${ }^{1}$ Facultad de Química, Departamento de Ingeniería Metalúrgica, Universidad Nacional Autónoma de México, C.U., Ciudad de México, C.P. 04510.

${ }^{2}$ Departamento de Ciencias Básicas, Universidad Autónoma Metropolitana-Azcapotzalco Av. San

Pablo No. 180 Col. Reynosa-Tamaulipas, México, Ciudad de México., C. P. 02200.

${ }^{3}$ Facultad de Estudios Superiores Zaragoza, Universidad Nacional Autónoma de México, Batalla 5 de Mayo s/n, esquina Fuerte de Loreto, Ciudad de México, C.P. 09230, México.

*E-mail: $\underline{\text { arasv_21@yahoo.com.mx }}$

doi: $10.20964 / 2018.12 .64$

Received: 28 August 2018 / Accepted: 1 October 2018 / Published: 5 November 2018

In this study, the corrosion inhibition of monotriazoles derived from uracil and thymine was studied with electrochemical impedance spectroscopy (EIS) on API 5L X52 steel in $1 \mathrm{M} \mathrm{H}_{2} \mathrm{SO}_{4}$. The addition of compounds diminished the corrosion process of the steel, with MTBU-I and MTBT-Br being the best corrosion inhibition compounds with an $\eta$ of $91 \%$ at $15 \mathrm{ppm}$. Furthermore, the persistence of the film showed that both compounds are effective up to 48 hours with an $\eta$ above $90 \%$, and at higher temperatures, the MTBT-Br provides a resistant film over the metallic surface up to $50{ }^{\circ} \mathrm{C}$. Hydrodynamic conditions demonstrated that the MTBT-Br afforded good protection against corrosion up to $100 \mathrm{rpm}$. According to their Langmuir isotherms, the adsorption process for these molecules is a combination of physisorption and chemisorption. Finally, SEM images show a decrease in the corrosion rate on the metallic surface in the presence of the MTBU-I or MTBT-Br.

Keywords: monotriazoles, API 5L X52, EIS, inhibitor, uracil, thymine

\section{FULL TEXT}

(C) 2018 The Authors. Published by ESG (www.electrochemsci.org). This article is an open access article distributed under the terms and conditions of the Creative Commons Attribution license (http://creativecommons.org/licenses/by/4.0/). 